\title{
Oleate protects against palmitate-induced insulin resistance in L6 myotubes
}

\author{
Dan Gao, Helen R. Griffiths* and Clifford J. Bailey \\ School of Life and Health Sciences, Aston University, Birmingham B4 7ET, UK \\ (Received 12 February 2009 - Revised 29 April 2009 - Accepted 26 May 2009 - First published online 22 July 2009)
}

Oleate has been shown to protect against palmitate-induced insulin resistance. The present study investigates mechanisms involved in the interaction between oleate and palmitate on insulin-stimulated glucose uptake by L6 skeletal muscle cells. L6 myotubes were cultured for $6 \mathrm{~h}$ with palmitate or oleate alone, and combinations of palmitate with oleate, with and without phosphatidylinositol 3-kinase (PI3-kinase) inhibition. Insulin-stimulated glucose uptake, measured by uptake of 2-deoxy-D- $\left[{ }^{3} \mathrm{H}\right]$ glucose, was almost completely prevented by $300 \mu \mathrm{M}-\mathrm{palmitate}$. Cells incubated with oleate up to $750 \mu \mathrm{mol} / 1$ maintained a significant increase in insulin-stimulated glucose uptake. Co-incubation of 50-300 $\mu \mathrm{M}$-oleate with $300 \mu \mathrm{M}$-palmitate partially prevented the decrease in insulin-stimulated glucose uptake associated with palmitate. Adding the PI3-kinase inhibitors wortmannin $\left(10^{-7} \mathrm{~mol} / \mathrm{l}\right)$ or LY294002 $(25 \mu \mathrm{mol} / \mathrm{l})$ to $50 \mu \mathrm{M}$-oleate plus $300 \mu \mathrm{M}$-palmitate significantly reduced the beneficial effect of oleate against palmitate-induced insulin resistance, indicating that activation of PI3-kinase is involved in the protective effect of oleate. Thus, the prevention of palmitate-induced insulin resistance by oleate in L6 muscle cells is associated with the ability of oleate to maintain insulin signalling through PI3-kinase.

NEFA: Insulin resistance: L6 muscle cells: Phosphatidylinositol 3-kinase

Insulin resistance, which describes an impaired response to physiological concentrations of insulin, is strongly associated with obesity and type 2 diabetes, and contributes to cardiovascular risk ${ }^{(1-3)}$. Excess accumulation of saturated lipid, especially in skeletal muscle which is the major site of insulin-stimulated glucose uptake, is an important factor in the development of insulin resistance ${ }^{(4-6)}$. Since insulin signalling to regulate glucose uptake in muscle is mediated largely through a pathway dependent upon phosphatidylinositol 3-kinase (PI3-kinase) and Akt phosphorylation, the effects of lipids on this pathway provide an important focus for the study of lipid-induced insulin resistance ${ }^{(7-9)}$.

Insulin resistance caused by cellular lipid accumulation is mainly associated with $\mathrm{SFA}^{(10)}$. Palmitate, one of the most abundant SFA, representing about $30 \%$ of the total NEFA in human plasma, has been shown to induce insulin resistance in cultured skeletal muscle cells and adipocytes ${ }^{(11,12)}$. By contrast, oleate, representing about $90 \%$ of the monounsaturated NEFA and $30 \%$ of the total NEFA in human plasma, has not been reported to cause significant insulin resistance. Recent studies have shown that combination of oleate with palmitate can reverse palmitate-induced alterations in insulin signal transduction ${ }^{(13-15)}$. These studies also suggested that the oleate:palmitate ratio may influence the protective effect of oleate. However, these studies have not examined the effect of oleate on palmitate-induced insulin resistance at the level of glucose uptake.
The present study examines whether oleate protects against palmitate-induced insulin resistance at the level of glucose uptake in cultured rat L6 muscle cells. The study also investigates whether the PI3-kinase pathway is involved, and whether the morphology and viability of the cells are affected by palmitate and/or oleate.

\section{Materials and methods}

\section{Materials}

The L6 rat skeletal muscle cell line was obtained from the European Culture Collection (Porton Down, UK). Dulbecco's modified Eagle's medium (DMEM), fetal bovine serum (FBS), an antibiotic and trypsin-EDTA were purchased from Cambrex (Verviers, Belgium). Sodium palmitate, sodium oleate, fatty acid-free bovine serum albumin (BSA), sodium pyruvate, PI3-kinase inhibitors (wortmannin and LY294002), trypan blue solution and 3-(4,5-dimethylthiazol-2-yl)-2, 5-diphenyltetrazolium bromide (MTT) were purchased from Sigma (Poole, UK). 2-Deoxy-D-[ $\left.{ }^{3} \mathrm{H}\right]$ glucose $(555 \mathrm{GBq} / \mathrm{mmol})$ was from Amersham International (Little Chalfont, Bucks, UK).

\section{Cell culture}

L6 myoblasts were grown in DMEM containing 5\% heatinactivated FBS, 25 mM-D-glucose, 1 mM-sodium pyruvate,

Abbreviations: BSA, bovine serum albumin; DMEM, Dulbecco's modified Eagle's medium; FBS, fetal bovine serum; MTT, 3-(4,5-dimethylthiazol-2-yl)-2, 5-diphenyltetrazolium bromide; PI3-kinase, phosphatidylinositol 3-kinase.

* Corresponding author: Dr Helen R. Griffiths, fax +44 121359 0572, email h.r.griffiths@aston.ac.uk 
$1 \mathrm{mM}-\mathrm{L}$-glutamine, penicillin $(100 \mathrm{U} / \mathrm{ml})$ and streptomycin $(100 \mu \mathrm{g} / \mathrm{ml})$ as described previously ${ }^{(16)}$. Cells were maintained at $37^{\circ} \mathrm{C}$ with humidified $95 \%$ air and $5 \% \mathrm{CO}_{2}$. Experiments were undertaken in twenty-four-well plates seeded from preconfluent flasks with $5 \times 10^{4}$ cells in $1 \mathrm{ml}$. The cells were grown to 70-80\% confluence and the medium was changed to DMEM containing $0.5 \%$ FBS for $24 \mathrm{~h}$ which induces rapid differentiation and fusion of these myoblasts into myotubes ${ }^{(16)}$.

\section{Conjugation of fatty acids to bovine serum albumin}

A stock solution of palmitate $(200 \mathrm{mmol} / \mathrm{l})$ or oleate ( $100 \mathrm{mmol} / \mathrm{l})$ was prepared by dissolving sodium palmitate or sodium oleate into $70 \%$ ethanol and $0.1 \mathrm{M}-\mathrm{NaOH}$ as described previously ${ }^{(17)}$. Fatty acids were then complexed with $5 \%$ fatty acid-free BSA to a concentration of $5 \mathrm{mmol} / \mathrm{l}$ at $37^{\circ} \mathrm{C}$, stirring for $4 \mathrm{~h}$ and adjusted to $\mathrm{pH} \mathrm{7 \cdot 4}$. After sterilising through a $0 \cdot 2 \mu \mathrm{m}$ filter, both solutions were stored at $4^{\circ} \mathrm{C}$ for no longer than 2 weeks. A control solution was prepared by mixing $70 \%$ ethanol and $0.1 \mathrm{M}-\mathrm{NaOH}$ with $5 \%$ BSA in the absence of fatty acids.

\section{Incubation with fatty acids and phosphatidylinositol 3-kinase inhibitors}

L6 myotubes were incubated with various concentrations of palmitate $(50-300 \mu \mathrm{mol} / \mathrm{l})$ or oleate $(50-750 \mu \mathrm{mol} / \mathrm{l})$ alone, and combinations of $300 \mu \mathrm{M}$-palmitate with $50-300 \mu \mathrm{M}$ oleate for $6 \mathrm{~h}$. Palmitate $(300 \mu \mathrm{mol} / \mathrm{l})$ induces a time (0-6h)-dependent reduction in insulin-stimulated glucose uptake which is maximal at $6 \mathrm{~h}$ and does not induce significant toxicity $^{(18)}$. Further experiments to investigate any involvement of the PI3-kinase pathway in the effects of fatty acids were undertaken with and without the PI3-kinase inhibitors wortmannin $\left(10^{-7} \mathrm{~mol} / \mathrm{l}\right)$ for $6 \mathrm{~h}$ or LY294002 $(25 \mu \mathrm{mol} / \mathrm{l})$ for $1 \mathrm{~h} 10 \mathrm{~min}$ at $37^{\circ} \mathrm{C}$. The presence of wortmannin at $10^{-7} \mathrm{~mol} / \mathrm{l}$ elicited a reduction of insulin-stimulated glucose uptake by L6 muscle cells over $6 \mathrm{~h}$, from 140.5 (SEM 4.8) to 105.5 (SEM 3.2) \% of non-insulin-stimulated glucose uptake $(P<0.001 ; n 8)$. Similarly, pre-incubation of L6 muscle cells with LY294002 for $10 \mathrm{~min}(25 \mu \mathrm{mol} / \mathrm{l})$ reduced insulinstimulated glucose uptake by L6 muscle cells from 150.1 (SEM 11.5) to 93.3 (SEM 4.6) \% of non-insulin-stimulated glucose uptake $(P<0 \cdot 001 ; n 9)$. Control cells received BSA and/or other vehicles as appropriate.

\section{2-Deoxy-D-glucose uptake}

2-Deoxy-D-glucose uptake was undertaken immediately after completion of the $6 \mathrm{~h}$ incubation with fatty acids in which insulin $\left(10^{-6} \mathrm{~mol} / \mathrm{l}\right)$ had been added for the last $1 \mathrm{~h}$. L6 myotubes were then washed with glucose-free Krebs-Ringer bicarbonate buffer at $22^{\circ} \mathrm{C}$ and incubated with $0.5 \mathrm{ml}$ of this buffer supplemented with $0.1 \mathrm{~mm}$-2-deoxy-D-glucose and 2-deoxy-D- $\left[{ }^{3} \mathrm{H}\right]$ glucose $(3700 \mathrm{~Bq} / \mathrm{ml})$ for $10 \mathrm{~min}$ at $22^{\circ} \mathrm{C}$. After washing cells three times with ice-cold Krebs-Ringer bicarbonate buffer, cells were lysed with $0.5 \mathrm{ml}$ of $1 \mathrm{M}-\mathrm{NaOH}$ and radioactivity was counted in $5 \mathrm{ml} \mathrm{Hi-safe} 3$ scintillant using a Packard 1900 TR liquid scintillation counter (Packard, Chicago, IL, USA). Uptake of 2-deoxy-D-glucose was expressed as the percentage compared with control $(100 \%)$, which was typically $5-8 \mathrm{pmol} / 10^{5}$ cells per min for basal uptake of 2-deoxy-D-glucose in the present studies as reported previously ${ }^{(19)}$.

\section{Cell viability assays}

Trypan blue exclusion assay. For the trypan blue exclusion assay, L6 myotubes in twenty-four-well plates were gently washed with PBS, and trypsinised with $100 \mu$ l trypsin-EDTA for $2 \mathrm{~min}$ and neutralised with $100 \mu \mathrm{l}$ DMEM with $10 \%$ FBS. After mixing with $0.4 \%$ trypan blue solution, the live cells were counted on a Neubauer haemocytometer (AO Scientific, Buffalo, NY, USA). Cell viability was expressed as percentage of live cells.

Caspase-3 activity assay. L6 myotubes in six-well plates were gently washed twice with ice-cold PBS. After application of lysis buffer (10 mM-2-amino-2-hydroxymethyl-propane1,3-diol- $\mathrm{HCl}, \mathrm{pH} 7 \cdot 5,130 \mathrm{~mm}-\mathrm{NaCl}, 1 \%$ TritonX-100,

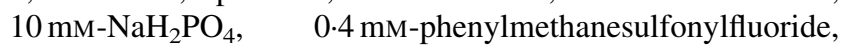
$0.2 \mathrm{~mm}-\mathrm{NaF}, 0.2 \mathrm{~mm}-\mathrm{Na}_{3} \mathrm{VO}_{4}$, leupeptin $\left.(0.3 \mathrm{mg} / \mathrm{ml})\right)$ on ice for $30 \mathrm{~min}$, cells were centrifuged at $10000 \mathrm{~g}$ for $5 \mathrm{~min}$. The supernatant fraction was collected and caspase-3 activity was measured using a fluorescent caspase-3 substrate II (7-amino-4-methylcoumarin, $\mathrm{N}$-acetyl-L-aspartyl-L-glutamylL-valyl-L-aspartic acid amide; Ac-DEVD-AMC) ${ }^{(20)}$ and protein content was measured by bicinchoninic acid protein assay ${ }^{(21)}$.

3-(4,5-Dimethylthiazol-2-yl)-2,5-diphenyltetrazolium bromide assay. For the MTT assay, the medium from treated and control L6 myotubes in twenty-four-well plates was removed and replaced with $0.5 \mathrm{ml}$ fresh DMEM with $0.5 \%$ FBS. Cells were then incubated with $100 \mu$ l MTT solution $\left(10 \mathrm{mg} / \mathrm{ml}\right.$ in PBS) for $4 \mathrm{~h}$ at $37^{\circ} \mathrm{C}$. Lysis buffer $(100 \mu \mathrm{l}$; $20 \%$ SDS in $50 \%$ dimethyl formamide, $\mathrm{pH} 4.7$ ) was added to each well and the plates were incubated for a further $16 \mathrm{~h}$ at $37^{\circ} \mathrm{C}$ in a humidified $5 \% \mathrm{CO}_{2}$ air incubator. The absorbance was read at $570 \mathrm{~nm}$ using an MRX Microplate reader (Dynex Technologies Limited, Worthing, West Sussex, UK). Blank wells contained DMEM without cells.

\section{Phase-contrast microscopy}

To assess cell morphology, L6 myotubes were photographed under a phase-contrast microscope (Olympus, Southendon-Sea, Essex, UK) at magnification $\times 20$.

\section{Statistical analysis}

Data are expressed as mean values with their standard errors, and 2-deoxy-D-glucose uptake is expressed as percentage compared with control (100\%). Statistical analyses were performed by one-way ANOVA with Tukey-Kramer post hoc tests. $P<0.05$ was considered significant.

\section{Results}

\section{Effect of palmitate or oleate alone on glucose uptake}

Initial experiments were conducted to characterise the effect of palmitate and oleate alone on basal and insulin-stimulated glucose uptake by L6 myotubes. Since palmitate was 
conjugated to BSA, the control and the oleate incubations were conducted with the same concentration of BSA. L6 myotubes were incubated with palmitate $(50-300 \mu \mathrm{mol} / \mathrm{l})$ or oleate $(50-750 \mu \mathrm{mol} / \mathrm{l})$ alone for $6 \mathrm{~h}$. Both palmitate and oleate at the concentrations tested showed no significant effect on basal glucose uptake compared with controls (Fig. 1(a), (b)). When BSA-treated control cells were stimulated with $10^{-6} \mathrm{M}$-insulin for $1 \mathrm{~h}$, this produced a significant increase in glucose uptake by about $40-50 \%$ which is a maximal insulin-induced effect for these cells over this time period (data not shown). However, when L6 myotubes were incubated with palmitate for $6 \mathrm{~h}$, there was a concentration-dependent decrease in insulin-stimulated glucose uptake. Insulin-stimulated glucose uptake was almost completely prevented by exposure to $300 \mu \mathrm{M}$-palmitate (Fig. 1(a)). Therefore, this concentration of palmitate was chosen to induce insulin resistance in subsequent studies.

Oleate alone caused a small concentration-dependent decrease in insulin-stimulated glucose uptake. The highest oleate concentration tested $(750 \mu \mathrm{mol} / \mathrm{l})$ did not completely prevent insulin-stimulated glucose uptake (Fig. 1(b)).

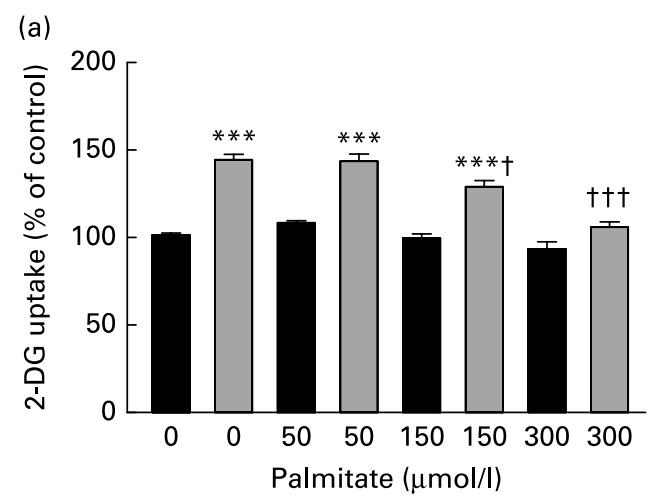

(b)

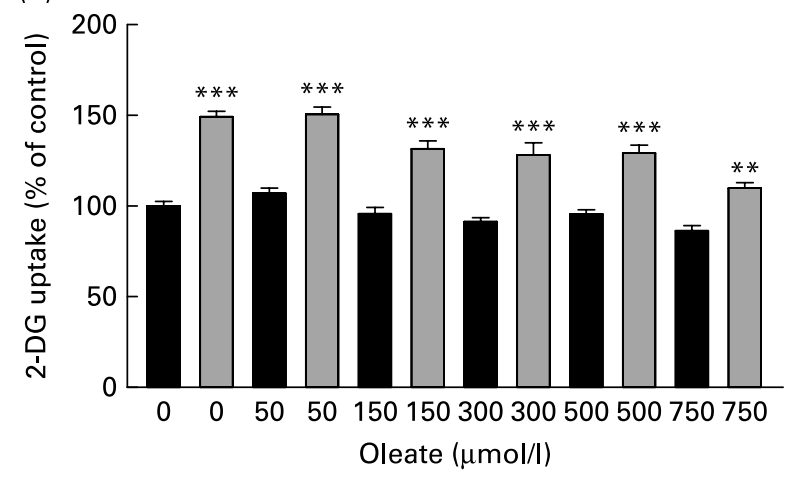

Fig. 1. Effect of palmitate (a) and oleate (b) alone on basal ( $\square$ ) and insulinstimulated ( $\square$ ) 2-deoxy-D-glucose (2-DG) uptake by L6 myotubes. L6 myotubes were incubated with bovine serum albumin (BSA) as control or BSA with palmitate $(50-300 \mu \mathrm{mol} / \mathrm{l})$ and oleate $(50-750 \mu \mathrm{mol} / \mathrm{l})$ alone for $6 \mathrm{~h}$ at $37^{\circ} \mathrm{C}$. Insulin $\left(10^{-6} \mathrm{~mol} / \mathrm{l}\right)$ was added for the last $1 \mathrm{~h}$ of incubation. Data are the means of three independent experiments performed in triplicate, with standard errors represented by vertical bars. Mean value was significantly different from that of the same treatment without insulin addition: ${ }^{\star *} P<0.01,{ }^{\star \star *} P<0.001$. Mean value was significantly different from that of the insulin-stimulated BSA-only-treated control $(0 \mu \mathrm{M}$-palmitate): $\dagger P<0.05$, †† $P<0.001$
Oleate protects L6 cells from palmitate-induced insulin resistance

The effect of oleate on palmitate-induced insulin resistance was examined by co-incubating increasing concentrations of oleate (50, 150 and $300 \mu \mathrm{mol} / \mathrm{l})$ with $300 \mu \mathrm{M}$-palmitate for $6 \mathrm{~h}$ with and without $10^{-6} \mathrm{M}$-insulin stimulation for the last $1 \mathrm{~h}$. Whereas $300 \mu \mathrm{M}$-palmitate alone abolished insulin-stimulated glucose uptake, co-incubation with oleate $(50 \mu \mathrm{mol} / \mathrm{l})$ partially restored (to $75 \%$ ) insulin-stimulated glucose uptake in the presence of $300 \mu \mathrm{M}$-palmitate, but co-incubation with $50 \mu \mathrm{M}$ BSA (control) did not exert any protective effect against the inhibition of insulin-stimulated glucose uptake by palmitate. The protective effect of oleate against palmitate-induced insulin resistance was not further affected by increasing the oleate concentration to $300 \mu \mathrm{mol} / \mathrm{l}$ (Fig. 2).

\section{Effects of fatty acids on L6 cell viability}

To test whether fatty acids have adverse effects on L6 myotubes, membrane integrity was assessed by trypan blue exclusion, and mitochondrial-reducing capacity was measured by an MTT assay.

Cells incubated with $300 \mu \mathrm{M}$-oleate alone did not show any significant difference in membrane integrity compared with BSA controls. With $300 \mu \mathrm{M}$-palmitate, there was a slight reduction in membrane integrity compared with BSA controls (viability of 74 (SEM 4) v. 88 (SEM 3) \%; $P<0 \cdot 001)$. Co-incubating cells with $50-300 \mu \mathrm{M}$-oleate prevented the slight reduction in membrane integrity with $300 \mu \mathrm{M}$-palmitate (Fig. 3).

The overall pattern in mitochondrial-reducing activity was similar to that of membrane integrity. Palmitate $(300 \mu \mathrm{mol} / \mathrm{l})$ decreased mitochondrial-reducing activity by more than $50 \%(P<0.001)$, whereas the same concentration of oleate $(300 \mu \mathrm{mol} / \mathrm{l})$ caused a $25 \%$ decrease in mitochondrialreducing activity compared with BSA controls. Addition of $150 \mu \mathrm{M}$ - and $300 \mu \mathrm{M}$-oleate with $300 \mu \mathrm{M}$-palmitate partially

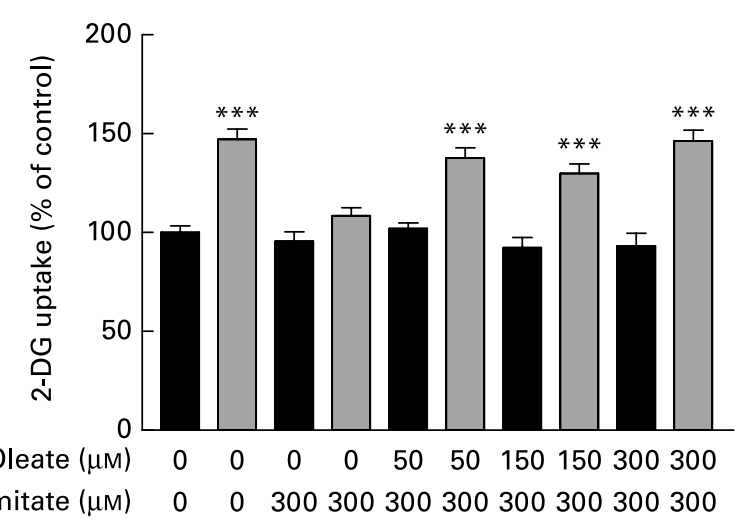

Fig. 2. Effect of combinations of $300 \mu \mathrm{M}$-palmitate with various concentrations of oleate on basal $(\square)$ and insulin-stimulated $(\square)$ 2-deoxy-D-glucose (2-DG) uptake by L6 myotubes. L6 myotubes were incubated with $300 \mu \mathrm{M}-$ palmitate and oleate $(50,150,300 \mu \mathrm{mol} / \mathrm{l})$ or $50 \mu \mathrm{M}$-bovine serum albumin as control for $6 \mathrm{~h}$ at $37^{\circ} \mathrm{C}$. Insulin $\left(10^{-6} \mathrm{~mol} / \mathrm{l}\right)$ was added for the last $1 \mathrm{~h}$ of incubation. Data are the means of three independent experiments performed in triplicate, with standard errors represented by vertical bars. ${ }^{* \star *}$ Mean value was significantly different from that of the same treatment without insulin addition $(P<0.001)$. 

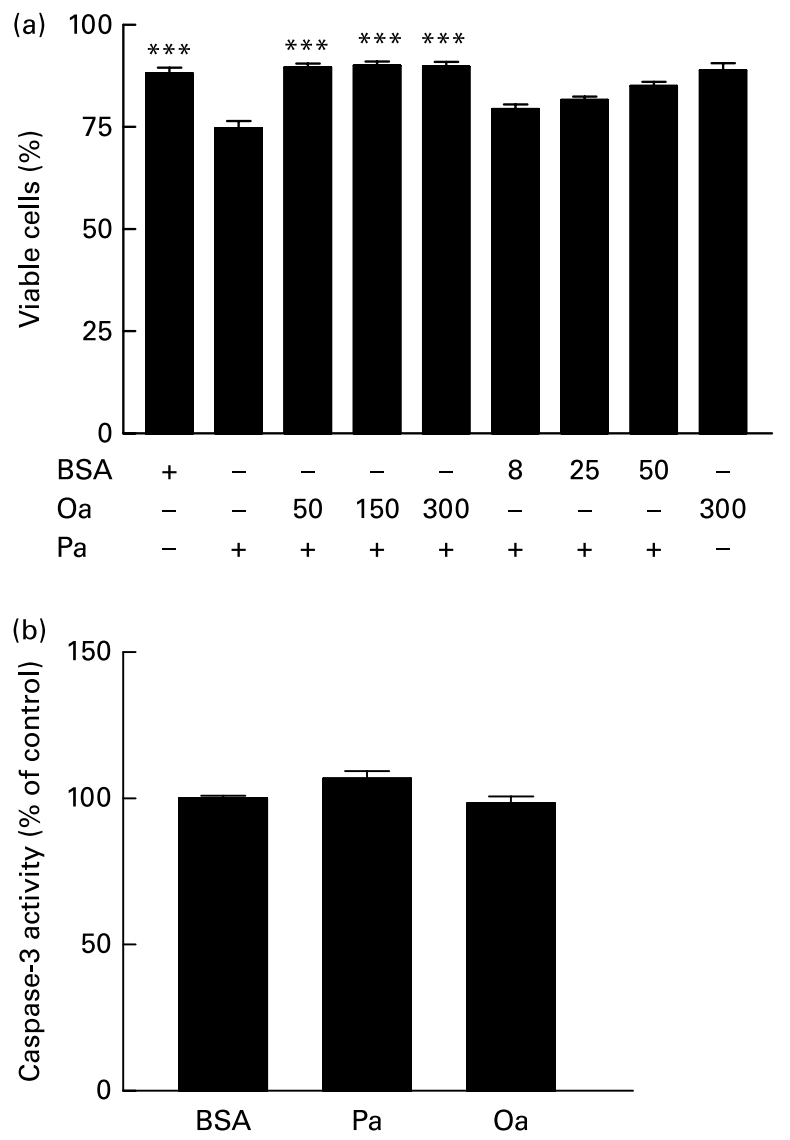

Fig. 3. Effect of palmitate $(\mathrm{Pa})$ and oleate $(\mathrm{Oa})$ on viability measured as (a) membrane integrity by trypan blue exclusion and (b) caspase-3 activity in cell lysates. (a) L6 myotubes were incubated with $300 \mu \mathrm{M}-\mathrm{Pa}$ and $300 \mu \mathrm{M}-\mathrm{Oa}$ alone and combinations of $300 \mu \mathrm{M}-\mathrm{Pa}$ with various concentrations of $\mathrm{Oa}$ $(50,150,300 \mu \mathrm{mol} / \mathrm{l})$ or bovine serum albumin (BSA) for $6 \mathrm{~h}$ at $37^{\circ} \mathrm{C}$. Viable cells were counted after trypsinisation. (b) L6 myotubes were incubated with $\mathrm{BSA}, 300 \mu \mathrm{M}-\mathrm{Pa}$ and $300 \mu \mathrm{M}-\mathrm{Oa}$ alone for $6 \mathrm{~h}$ at $37^{\circ} \mathrm{C}$. Caspase- 3 activity in lysates was measured as the release of coumarin fluorescence from the synthetic peptide 7-amino-4-methylcoumarin, $\mathrm{N}$-acetyl-L-aspartyl-L-glutamylL-valyl-L-aspartic acid amide (Ac-DEVD-AMC). Data are the means of three independent experiments performed in triplicate, with standard errors represented by vertical bars. ${ }^{\star \star \star}$ Mean value was significantly different from that of the Pa-only treatment $(P<0.001)$.

prevented the decrease in mitochondrial-reducing activity associated with palmitate $(P<0 \cdot 001)$. A lower concentration of oleate $(50 \mu \mathrm{mol} / \mathrm{l})$ did not show a significant protective effect against the palmitate-induced decrease in mitochondrial-reducing activity $(P>0 \cdot 05)$ (Fig. 4).

\section{Oleate prevents the palmitate-induced alteration in L6 cell morphology}

There was a distinct difference between the effects of palmitate and oleate alone on L6 myotube morphology. When L6 myotubes were incubated with $300 \mu \mathrm{M}$-palmitate, the muscle cells lost their spindle shape (Fig. 5(b)), whereas cells incubated with the same concentration of oleate maintained a similar shape to BSA controls (Fig. 5(c)). When $50 \mu \mathrm{M}$-oleate was co-incubated with $300 \mu \mathrm{M}$-palmitate, the spindle shape was retained (Fig. 5(d)). This protective effect of oleate was not further enhanced when the oleate concentration was raised to 150 and $300 \mu \mathrm{mol} / \mathrm{l}$ (Fig. 5(e), (f)).
To exclude the possibility that BSA (a fatty acid carrier protein) could contribute to the protection by oleate, it was noted that the loss of spindle shape caused by palmitate was not prevented by co-incubating with increasing concentrations of BSA (Fig. 5(g), (h), (i)).

\section{Phosphatidylinositol 3-kinase activity in palmitate- and oleate-treated L6 cells}

To investigate the underlying mechanism of the protective effect of oleate against palmitate-induced insulin resistance in L6 myotubes, the involvement of PI3-kinase activation was examined by incubating L6 myotubes with two different types of PI3-kinase inhibitors: wortmannin which binds to the catalytic subunit (P110) and LY294002 which binds to the regulatory subunit (P85) of PI3-kinase ${ }^{(22)}$. Both wortmannin $\left(10^{-7} \mathrm{~mol} / \mathrm{l}\right)$ and LY294002 $(25 \mu \mathrm{mol} / \mathrm{l})$ slightly reduced basal glucose uptake by $10 \%(P<0.05)$ and prevented insulin-stimulated glucose uptake by L6 myotubes (Fig. 6(a), (b)). The reduction in insulin-stimulated glucose uptake by $300 \mu \mathrm{M}$-palmitate was partially prevented by co-incubating with $50 \mu \mathrm{M}$-oleate as tested earlier (Fig. 2). With the addition of wortmannin $\left(10^{-7} \mathrm{~mol} / \mathrm{l}\right)$ or LY294002 $(25 \mu \mathrm{mol} / \mathrm{l})$, the improvement in insulin-stimulated glucose uptake by $50 \mu \mathrm{M}$ oleate in $300 \mu \mathrm{M}$-palmitate-treated cells was significantly reduced $(P<0 \cdot 001)$ (Fig. 6(a), (b)).

\section{Discussion}

In the present study, the effect of oleate on palmitate-induced insulin resistance at the level of glucose transport was investigated in L6 myotubes. Treating L6 cells with $300 \mu \mathrm{M}$-palmitate for $6 \mathrm{~h}$ almost completely abolished insulin-stimulated glucose uptake. Oleate (up to $750 \mu \mathrm{mol} / \mathrm{l}$ ) produced only a slight reduction in insulin-stimulated

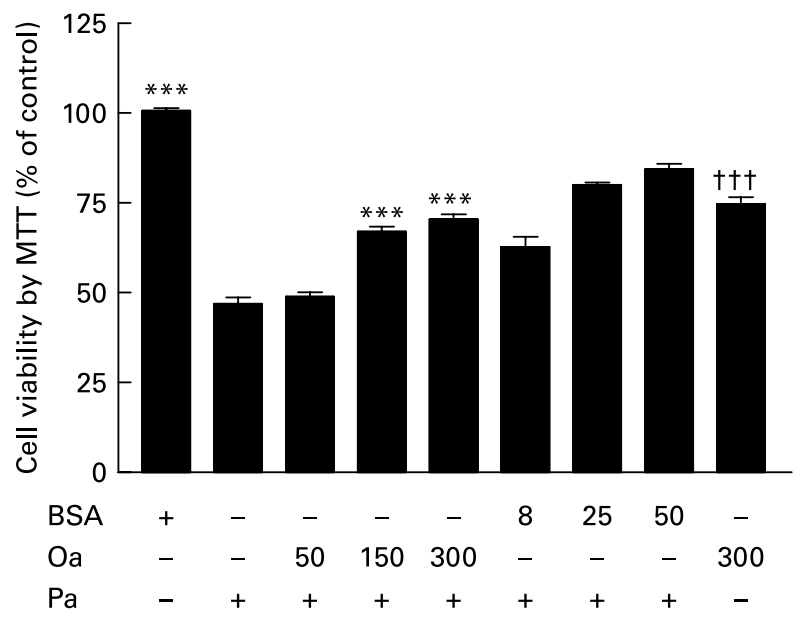

Fig. 4. Effect of palmitate $(\mathrm{Pa})$ and oleate $(\mathrm{Oa})$ on mitochondrial-reducing activity measured by 3-(4,5-dimethylthiazol-2-yl)-2,5-diphenyltetrazolium bromide (MTT) assay. L6 myotubes were incubated with $300 \mu \mathrm{M}-\mathrm{Pa}$ and $300 \mu \mathrm{M}-\mathrm{Oa}$ alone and combinations of $300 \mu \mathrm{M}-\mathrm{Pa}$ with various concentrations of $\mathrm{Oa}(50,150,300 \mu \mathrm{mol} / \mathrm{l})$ or bovine serum albumin (BSA) for $6 \mathrm{~h}$ at $37^{\circ} \mathrm{C}$. Data are the means of three independent experiments performed in triplicate, with standard errors represented by vertical bars. ${ }^{\star \star \star}$ Mean value was significantly different from that of the $\mathrm{Pa}$-only treatment $(P<0.001)$. ††† Mean value was significantly different from that of the BSAonly treatment $(P<0.001)$. 
(a)

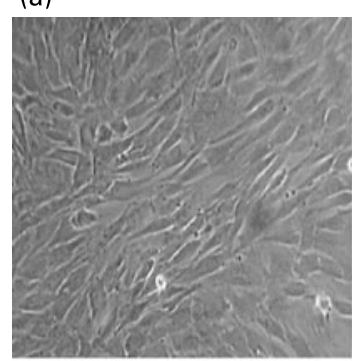

(d)

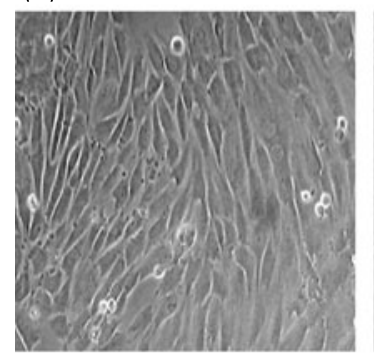

(g)

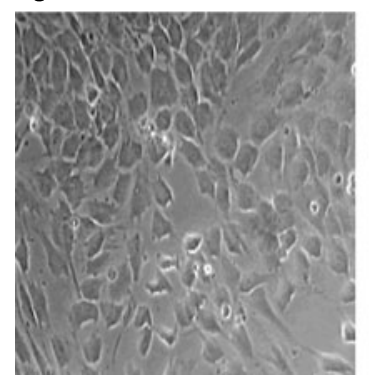

(b)

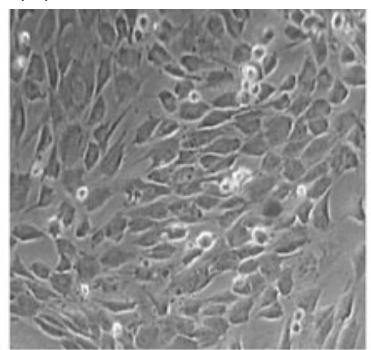

(e)

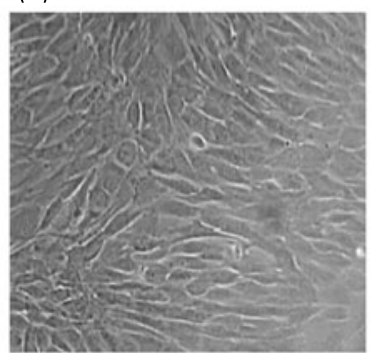

(h)

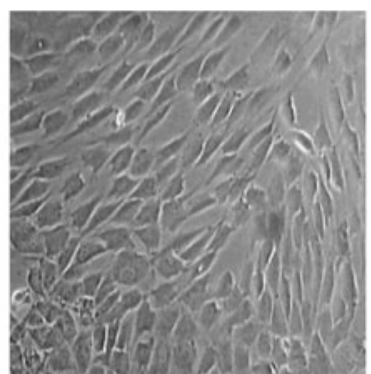

(c)

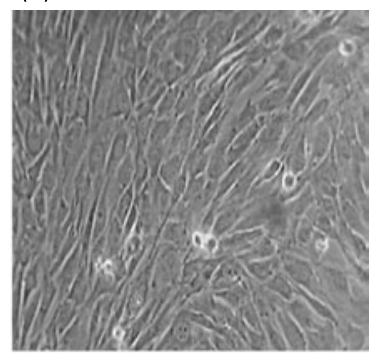

(f)

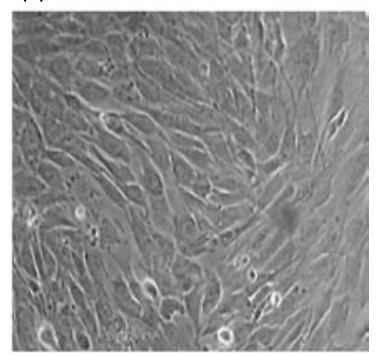

(i)

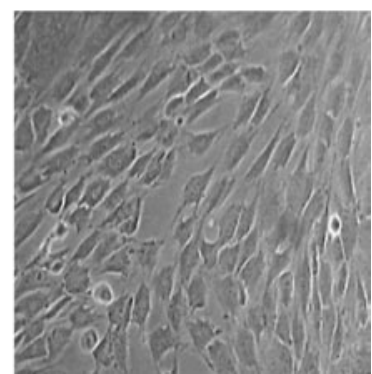

Fig. 5. Effect of palmitate $(\mathrm{Pa})$, oleate $(\mathrm{Oa})$, combinations of palmitate with various concentrations of Oa or bovine serum albumin (BSA) on L6 myotube morphology. L6 myotubes were incubated with $300 \mu \mathrm{M}-\mathrm{Pa}$ and $300 \mu \mathrm{M}-\mathrm{Oa}$ alone and combinations of $300 \mu \mathrm{M}$-Pa with various concentrations of Oa (50, 150 , $300 \mu \mathrm{mol} / \mathrm{l})$ or BSA $(8,25,50 \mu \mathrm{mol} / \mathrm{l})$ for $6 \mathrm{~h}$ at $37^{\circ} \mathrm{C}$. The cell cultures were photographed using an inverted phase-contrast light microscope at magnification $\times$ 20. (a) BSA control; (b) $300 \mu \mathrm{M}-\mathrm{Pa}$; (c) $300 \mu \mathrm{M}-\mathrm{Oa}$; (d) $\mathrm{Pa}+50 \mu \mathrm{M}-\mathrm{Oa}$; (e) $\mathrm{Pa}+150 \mu \mathrm{M}-\mathrm{Oa}$; (f) $\mathrm{Pa}+300 \mu \mathrm{M}-\mathrm{Oa}$; (g) Pa $+8 \mu \mathrm{M}-\mathrm{BSA}$; (h) Pa +25 $\mu \mathrm{M}-\mathrm{BSA}$; (i) $\mathrm{Pa}+50 \mu \mathrm{M}-\mathrm{BSA}$.

glucose uptake. However, addition of $50 \mu \mathrm{M}$-oleate reduced the inhibitory effect of $300 \mu \mathrm{M}$-palmitate on insulin-stimulated glucose uptake. This protective effect was not further increased with increasing concentrations of oleate up to $300 \mu \mathrm{mol} / \mathrm{l}$ but required the activity of PI3-kinase.

Fatty acid-induced insulin resistance has been extensively studied in vitro using skeletal muscle cells ${ }^{(13,20)}$. In L6 cells palmitate $(300 \mu \mathrm{mol} / \mathrm{l})$ reduced insulin-stimulated glucose uptake acutely $(6 \mathrm{~h})$, confirming previous studies with these cells ${ }^{(23)}$.

Two distinct fatty acid metabolites formed from oversupply of lipids to skeletal muscle have been implicated in the development of skeletal muscle insulin resistance: ceramide and diacylglycerol ${ }^{(24)}$. Palmitate is an important precursor of de novo synthesis of ceramide ${ }^{(25)}$, and ceramide strongly inhibits insulin action ${ }^{(26,27)}$, mainly by disrupting activation of Akt (protein kinase B) and reducing translocation of GLUT into the cell membrane ${ }^{(28-30)}$. Studies of lipid-induced insulin resistance in muscles of animals and human subjects support a role of diacylglycerol in the activation of the protein kinase $\mathrm{C} \theta-\mathrm{NF}-\kappa \mathrm{B}$ pathway ${ }^{(31)}$. This involves serine phosphorylation of insulin receptor substrate-1 and an associated reduction of PI3-kinase activity ${ }^{(32)}$.
Although oleate alone (up to $750 \mu \mathrm{mol} / \mathrm{l}$ ) slightly reduced insulin-stimulated glucose uptake by L6 myotubes, only $50 \mu \mathrm{M}$-oleate was required to prevent $300 \mu \mathrm{M}$-palmitateinduced insulin resistance. This observation is consistent with a recently published study in which $100 \mu \mathrm{M}$-oleate reversed $500 \mu \mathrm{M}$-palmitate-induced insulin resistance in C2C12 myotubes; this effect involved altered phosphorylation of $\mathrm{Akt}^{(15)}$. Using the PI3-kinase inhibitors, wortmannin and LY294002, we have demonstrated that the effect of oleate to partially reverse palmitate-induced insulin resistance requires PI3-kinase activity, which is an insulin-signalling intermediate between insulin receptor substrate-1 and the 3-phosphoinositide-dependent kinase that regulates Akt. It is anticipated that reactivation of this pathway will restore GLUT-4 translocation and glucose transport ${ }^{(33)}$. It has been reported previously that long-term exposure to oleate can stimulate the activation of PI3-kinase in MDA-MB-231 cancer cells ${ }^{(34)}$. Since the present study involves only $6 \mathrm{~h}$ exposure to oleate, the effect of oleate on PI3-kinase is unlikely to be a direct effect on gene expression. Also, oleate alone did not increase insulin-stimulated glucose uptake.

It has been proposed that palmitate-induced insulin resistance could be mediated via protein kinase $\mathrm{C} \theta$-induced 


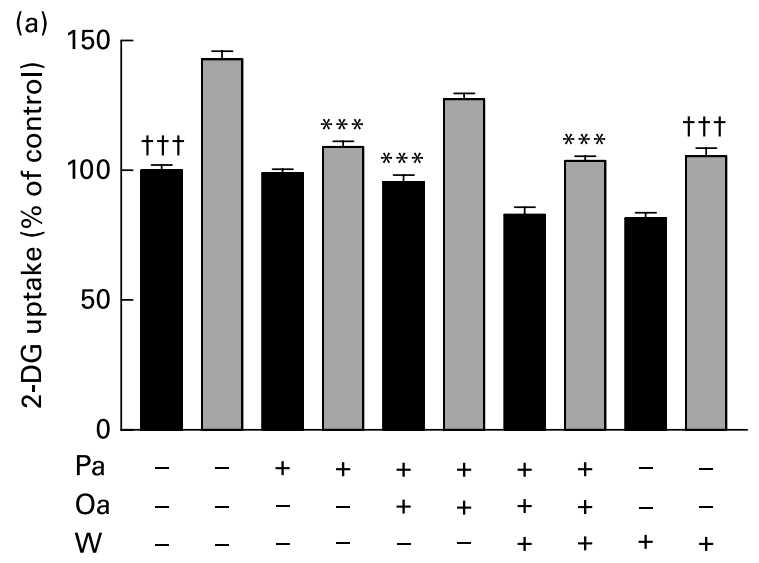

(b)

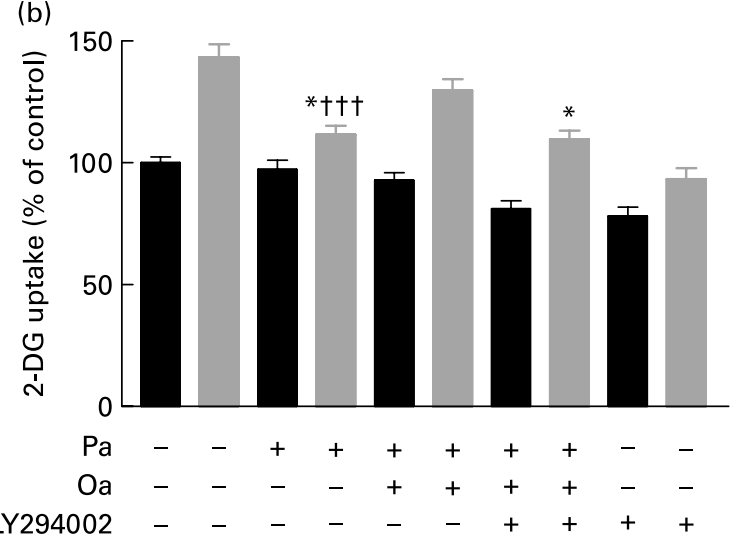

Fig. 6. Effect of phosphatidylinositol 3-kinase inhibitors on basal ( $\square$ ) and insulin-stimulated ( $\square$ ) 2-deoxy-D-glucose (2-DG) uptake by L6 myotubes in the presence of palmitate $(\mathrm{Pa})$ plus oleate $(\mathrm{Oa})$. L6 myotubes were incubated with $300 \mu \mathrm{M}-\mathrm{Pa}$ and $50 \mu \mathrm{M}-\mathrm{O}$ a with and without wortmannin (W) $\left(10^{-7} \mathrm{~mol} / \mathrm{l}\right)$ (a) for $6 \mathrm{~h}$ or LY294002 $(25 \mu \mathrm{mol} / \mathrm{l})$ (b) for $10 \mathrm{~min}$ at $37^{\circ} \mathrm{C}$. Insulin $\left(10^{-6} \mathrm{~mol} / \mathrm{l}\right)$ was added for the last $1 \mathrm{~h}$ of incubation. Data are the means of three independent experiments performed in triplicate, with standard errors represented by vertical bars. Mean value was significantly different from that of the insulin-stimulated $\mathrm{Pa}+$ Oa-only-treatment: ${ }^{\star} P<0.05,{ }^{* \star \star} P<0.001$. ††† Mean value was significantly different from that of the insulin-stimulated $\mathrm{Pa}$-, Oa- and inhibitor-absent treatment $(P<0.001)$.

serine-phosphorylation to suppress insulin receptor substrate-1, which then reduces PI3-kinase activity ${ }^{(32,35)}$. Activation of protein kinase $\mathrm{C} \theta$ is promoted by diacylglycerol, which is generated from palmitate or by inhibitor $\kappa \mathrm{B}$ kinase $\beta$, a serine kinase that normally prevents activation of NF- $\mathrm{B}^{(23)}$. Oleate has been reported to inhibit the activation of NF- $\mathrm{KB}$ in endothelial cells ${ }^{(36)}$. Therefore, the protective effect of oleate against palmitate could be due to suppression of the protein kinase $\mathrm{C} \theta$ and NF-кB pathways. Thus, oleate protection against palmitate-induced insulin resistance may result from the channelling of diacylglycerol into neutral TAG which does not induce insulin resistance ${ }^{(13-15,37-39)}$. It remains to be investigated whether ceramide generation is involved in the protection by oleate against palmitate-induced insulin resistance.

Another detrimental effect of palmitate observed in the present study was the loss of spindle shape of L6 myotubes. Normal cell morphology was restored by co-incubation with $50 \mu \mathrm{M}$-oleate, and this was associated with a small increase in membrane integrity. However, the reduction in membrane integrity was much smaller than the reduction in insulin-stimulated glucose uptake caused by palmitate, suggesting that the small loss in cell membrane integrity is not the primary contributor to the palmitate-induced insulin resistance in L6 myotubes. Mitochondrial dysfunction has been implicated in the development of insulin resistance ${ }^{(40)}$, and palmitate diminished the mitochondrial-reducing capacity of L6 cells. Nevertheless, the inability of $50 \mu \mathrm{M}$-oleate to restore mitochondrial function while reversing $300 \mu \mathrm{M}$-palmitate-induced insulin resistance suggests that improved mitochondrial function is not crucial for the protective effect of oleate against palmitate-induced insulin resistance in muscle. Addition of $150 \mu \mathrm{M}$ - and $300 \mu \mathrm{M}$-oleate partially prevented the palmitate-induced decrease in mitochondrial activity and this protective effect is similar to the addition of increasing concentrations of BSA. This suggests that the protection by the higher concentrations of oleate may partly reflect the increased amount of BSA. There was no effect of palmitate or oleate on apoptosis under the same conditions as assessed by caspase- 3 assay on the adherent cells. However, apoptotic cells can lose adherence, so additional measures of cell death are required to exclude an effect on apoptosis.

In summary, the present study has demonstrated a protective effect of the MUFA oleate against insulin resistance induced by the SFA palmitate in L6 muscle cells. This protective effect is associated with the ability of oleate to preserve insulin-stimulated PI3-kinase activity in palmitate-treated cells. The protective effect of oleate has potentially important implications for the balance of dietary monounsaturated and saturated fats in the development of insulin resistance and these data suggest possible benefits of increasing plasma oleate in vivo; an early meta-analysis of dietary fat intake supported the hypothesis that monounsaturated fat may improve diabetic control and this has been substantiated by more recent studies ${ }^{(41-43)}$. Whether dietary oleate offers a strategy to improve glucose homeostasis in type 2 diabetes mellitus requires further investigation through well-designed, appropriately powered dietary intervention studies.

\section{Acknowledgements}

The authors gratefully acknowledge financial support for the present study from Aston University and for D. G. from an Overseas Research Students Awards Scheme (ORSAS) scholarship award.

D. G. undertook all experiments and drafted the manuscript. H. R. G. was principal investigator and supervisor to D. G. and C. J. B. was associate supervisor.

The authors declare that there is no conflict of interest.

\section{References}

1. Mokdad AH, Ford ES, Bowman BA, et al. (2003) Prevalence of obesity, diabetes, and obesity-related health risk factors, 2001. JAMA 289, 76-79.

2. Kahn SE, Hull RL \& Utzscheider KM (2006) Mechanisms linking obesity to insulin resistance and type 2 diabetes. Nature 444, 840-846.

3. Ritchie SA \& Connell JMC (2007) The link between abdominal obesity, metabolic syndrome and cardiovascular disease. Nutr Metab Cardiovasc Dis 17, 319-326. 
4. Baron AD, Bretchel G, Wallace P, et al. (1988) Rates and tissue sites of non-insulin and insulin-mediated glucose uptake in humans. Am J Physiol 255, E769-E774.

5. Shulman GI (2000) Cellular mechanisms of insulin resistance. $J$ Clin Invest 106, 171-175.

6. McGarry JD (2002) Banting lecture: 2001: dysregulation of fatty acid metabolism in the aetiology of type 2 diabetes. Diabetes 51, 7-18.

7. Roden M, Price TB, Perseghin G, et al. (1996) Mechanism of free fatty acid-induced insulin resistance in humans. $J$ Clin Invest 97, 2859-2865.

8. Dresner A, Laurent D, Marcucci M, et al. (1998) Effects of free fatty acids on glucose transport and IRS1-associated phophatidylinositol 3-kinase activity. J Clin Invest 103, 253-259.

9. Kruszynska YT, Worrall DS, Ofrecio J, et al. (2002) Fatty acidinduced insulin resistance: decreased muscle PI3K activation but unchanged Akt phosphorylation. J Clin Endocrinol Metab 87, 226-234.

10. Lee JS, Pinnamaneni SK, Eo SJ, et al. (2006) Saturated, but not $n-6$ polyunsaturated, fatty acids induce insulin resistance: role of intramuscular accumulation of lipid metabolites. J Appl Physiol 100, 1467-1474.

11. Van Epps-Fung M, Williford J, Wells A, et al. (1997) Fatty acid-induced insulin resistance in adipocytes. Endocrinology 138, 4338-4345.

12. Chavez JA \& Summers SA (2003) Characterizing the effects of saturated fatty acids on insulin signalling and ceramide and diacylglycerol accumulation in 3T3-L1 adipocytes and $\mathrm{C} 2 \mathrm{C} 12$ myotubes. Arch Biochem Biophys 419, 101-109.

13. Sabin MA, Stewart CE, Crowne EC, et al. (2007) Fatty acidinduced defects in insulin signalling, in myotubes derived from children, are related to ceramide production from palmitate rather than the accumulation of intramyocellular lipid. $J$ Cell Physiol 211, 244-252.

14. Pickersgill L, Litherland GJ, Greenberg AS, et al. (2007) Key role for ceramides in mediating insulin resistance in human muscle cells. Biochem J 282, 12583-12589.

15. Coll T, Eyre E, Rodriguez-Calvo R, et al. (2008) Oleate reverses palmitate-induced insulin resistance and inflammation in skeletal muscle cells. J Biol Chem 283, 11107-11116.

16. Bailey CJ, Turner SL, Bates SH, et al. (2001) Sibutramine metabolites increase glucose transport by cultured rat muscle cells. Int J Obes Relat Metab Disord 25, 478-485.

17. Zhang WY, Schwartz E, Wang YJ, et al. (2006) Elevated concentrations of nonesterified fatty acids increase monocyte expression of $\mathrm{CD} 11 \mathrm{~b}$ and adhesion to endothelial cells. Arterioscler Thromb Vasc Biol 26, 514-519.

18. Gao D (2009) Palmitate induces insulin resistance and a pro-atherogenic phenotype in monocytes. PhD Thesis, Aston University, UK.

19. Bailey CJ \& Turner SL (2004) Glucosamine-induced insulin resistance in L6 muscle cells. Diabetes Obes Metab 6, 293-298.

20. Nicholson DW, Ali A, Thornberry NA, et al. (1995) Identification and inhibition of the ICE/CED-3 protease necessary for mammalian apoptosis. Nature 376, $37-43$.

21. Smith PK, Krohn RI, Hermanson GT, et al. (1985) Measurement of protein using bicinchoninic acid. Anal Biochem 150, 76-85.

22. Toker A \& Cantley CL (1997) Signalling through the lipid products of phosphoinositide-3-OH kinase. Nature 387, 673-676.

23. Sinha S, Perdomo G, Brown NF, et al. (2004) Fatty acidinduced insulin resistance in L6 myotubes is prevented by inhibition of activation and nuclear localization of nuclear factor $\kappa$ B. J Biol Chem 279, 41294-41301.

24. Boden G, Chen X, Ruiz J, et al. (1994) Mechanisms of fatty acid-induced inhibition of glucose uptake. J Clin Invest 93, $2423-2446$
25. Kolesnick RN \& Krönke M (1998) Regulation of ceramide production and apoptosis. Annu Rev Physiol 60, 643-665.

26. Hajduch E, Balendran A, Batty IH, et al. (2001) Ceramide impairs the insulin-dependent membrane recruitment of protein kinase B leading to a loss of downstream signalling in L6 skeletal muscle cells. Diabetologia 44, 173-183.

27. Summers SA, Garza LA, Zhou H, et al. (1998) Regulation of insulin-stimulated glucose transporter GLUT4 translocation and Akt kinase activity by ceramide. Mol Cell Biol 18, 5457-5464.

28. Schmitz-Peiffer C, Craig DL \& Biden TJ (1999) Ceramide generation is sufficient to account for the inhibition of the insulin-stimulated $\mathrm{PKB}$ pathway in $\mathrm{C} 2 \mathrm{C} 12$ skeletal muscle cells pretreated with palmitate. J Biol Chem 274, 24202-24210.

29. Chavez JA, Knotts TA, Wang LP, et al. (2003) A role for ceramide, but not diacylglycerol, in the antagonism of insulin signal transduction by saturated fatty acids. J Biol Chem 278, 10297-10303.

30. Powell D, Turban S, Gray A, et al. (2004) Intracellular ceramide synthesis and protein kinase $\mathrm{C} \zeta$ activation play an essential role in palmitate-induced insulin resistance in rat L6 skeletal muscle cells. Biochem J 382, 619-629.

31. Itani SI, Ruderman NB, Schmieder F, et al. (2002) Lipidinduced insulin resistance in human muscle is associated with changes in diacylglycerol, protein kinase $\mathrm{C}$, and ІкB- $\alpha$. Diabetes 51, 2005-2011.

32. Griffin ME, Marcucci MJ, Cline GW, et al. (1999) Free fatty acid-induced insulin resistance is associated with activation of protein kinase $\mathrm{C}$ theta and alterations in the insulin signalling cascade. Diabetes 48, 1270-1274.

33. Karlsson HKR \& Zierath JR (2007) Insulin signalling and glucose transport in insulin resistant human skeletal muscle. Cell Biochem Biophys 48, 103-113.

34. Hardy S, Langelier Y \& Prentki M (2000) Oleate activates phosphatidylinositol 3-kinase and promotes proliferation and reduces apoptosis of MDA-MB-231 breast cancer cells, whereas palmitate has opposite effects. Cancer Res 60, 6353-6358.

35. Kim JK, Fillmore JJ, Sunshine MJ, et al. (2004) PKC- $\theta$ knockout mice are protected from fat-induced insulin resistance. $J$ Clin Invest 114, 823-827.

36. Massaro M, Carluccio MA, Paolicchi A, et al. (2002) Mechanisms for reduction of endothelial activity by oleate: inhibition of nuclear factor-кB through antioxidant effects. Prostaglandins Leukot Essent Fatty Acids 67, 175-181.

37. Voshol PJ, Jong MC, Dahlmans VE, et al. (2001) In musclespecific lipoprotein lipase-overexpressing mice, muscle triglyceride content is increased without inhibition of insulinstimulated whole-body and muscle-specific glucose uptake. Diabetes 50, 2585-2590.

38. Conp M, Hannaert JC, Hoorrens A, et al. (2001) Inverse relationship between cytotoxicity of free fatty acids in pancreatic islet cells and cellular triglyceride accumulation. Diabetes 50, $1771-1777$.

39. Listenberger LL, Han XL, Lewis SE, et al. (2003) Triglyceride accumulation protects against fatty acid-induced lipotoxicity. Proc Natl Acad Sci U S A 100, 3077-3082.

40. Kelly DE, He J, Menshikova EV, et al. (2002) Dysfunction of mitochondria in human skeletal muscle in type 2 diabetes. Diabetes 51, 2944-2950.

41. Ros E (2003) Dietary cis-monounsaturated fatty acids and metabolic control in type 2 diabetes. Am J Clin Nutr 78, Suppl. 3, 617S-625S.

42. Garg A (1998) High-monounsaturated-fat diets for patients with diabetes mellitus: a meta-analysis. Am J Clin Nutr 67, Suppl. 3, 577S-582S.

43. Due A, Larsen TM, Hermansen K, et al. (2008) Comparison of the effects on insulin resistance and glucose tolerance of 6-month high-monounsaturated-fat, low-fat, and control diets. Am J Clin Nutr 87, 855-862. 